6056

Research Article

Journal of Extension Education

Vol. 30 No. 2, 2018

DOI:https://doi.org/10.26725/JEE.2018.2.30.6056-6061

\title{
Constraint Analysis of Livelihood Systems in Coral Ecosystem
}

\author{
Anshida Beevi ${ }^{1}$ and Jagriti Rohit ${ }^{2}$
}

\begin{abstract}
To secure people's livelihood security, it is important to determine the inhibiting factors so that necessary interventions may accordingly be made to create a conducive climate for them. A study was conducted in Lakshadweep islands of India to evaluate various constraints for sustainable livelihood approach. Respondents were classified into three livelihood classes based on their livelihood options. Results of the study showed that personal constraints followed by economic, promotional and infrastructural constraints were significantly different among people engaged in different livelihood options. Ecological and social constraints were not significantly different among groups. Multiple comparison of different groups showed that people depending on non-farm sector only (group 2) and those engaged in both farm and non-farm sector (group3) were on par regarding personal, economic and promotional \& infrastructural constraints.
\end{abstract}

Keywords: Constraints; Livelihood strategy; Lakshadweep islands; Sustainability

\section{INTRODUCTION}

Livelihoods are the sum of ways in which people make a living. Livelihood security of a household is defined as its ability to meet basic needs like food, health, shelter and minimal levels of income, basic education and community participation. A livelihood is said to be environmentally sustainable, when it maintains or enhances the local and global assets on which livelihood depend. Chambers (1988) has defined sustainable livelihood as a 'level of wealth and of stocks and flows of food and cash which provide for physical and social well-being and security against becoming poorer'. Swaminathan (1991a, b) has defined sustainable livelihood security as livelihood options that are ecologically secure, economically efficient, and socially equitable underscoring: ecology, economics and equity dimensions.

To secure peoples' livelihood security, it is important to determine the inhibiting factors so that necessary interventions may accordingly be made to create a conducive climate for them. Several studies have been made in this direction nationally and internationally. Sarah and Atchuta (2003) conducted a study on problems faced by farm women in managing enterprises in Guntur district of Andhra Pradesh and revealed that 92.50 per cent of the respondents

$1 \& 2$ Scientists, ICAR-CRIDA, Central Research Institute for Dryland Agriculture, Hyderabad -500059

Received : 14-11-2017; Accepted : 03-04-2018 
faced financial problems, 78.33 per cent of them expressed inaccessibility of place as a constraint followed by improper marketing facility, lack of guidance and non-availability of raw materials. Only 22.50 per cent of respondents expressed lack of competition and lack of experience as their constraints and 13.33 per cent of respondents expressed lack of family cooperation as a constraint. Savitha (2004) from her study on the role of rural women in animal husbandry in Dharwad district reported that majority of the respondents expressed the problems like nonavailability of fodder as their main problem (93.33\%), followed by water scarcity (90.00\%), low cost of milk (83.33\%). Letha Devi (2007) reported that one of the key reasons for the change in agricultural sector and the resultant change in the livelihood pattern of the society can be attributed to the phenomenon of increasing rate of urbanization.

Livelihoods are the means, activities and entitlements by which people make a living. Sustainable livelihood approach is a means for poverty elimination. It brings together the thinking and practice of poverty reduction strategies, sustainable development and participation and empowerment processes into a framework for policy analysis and programming. Sustainable livelihoods are a systemic and adaptive approach that links issues of poverty reduction, sustainability and empowerment processes. People living in extreme poverty and outside the formal labor market, for example, constantly improvise their livelihood strategies due to high uncertainty and limited options. A livelihood is sustainable if it can cope with, recover from and adapt to stresses and shocks, maintain and enhance its capabilities and assets, and enhance opportunities for the next generation. Coping strategies are often a short-term response to a specific shock such as drought. On the other hand, adaptive strategies entail a longterm change in behaviour patterns as a result of a shock or stress. A crucial element of the sustainable livelihood approach is the notion of mutuality and reciprocity. The approach provides a lens through which to view people and their environments in a reciprocal relationship. Thus, people are neither cast as powerless objects, nor as free agents who can become whatever they choose. In other words, there is a feedback loop not only between people themselves, but also between people and the political, social, economic situations in which they find themselves. In view of above context the present study was conducted to analyze different constraints to ensure the sustainability of livelihood systems.

\section{METHODOLOGY}

The study was conducted in Lakshadweep islands of India. A total of 120 respondents represented the sample of the study. Major constraints in the study area were identified through initial discussion with the respondents and from literature review. These were categorized into five different sets. With the help of a semi-structured interview schedule respondents were asked to rate these constraints on a three point continuum. The response scores were converted into ranks for one-way analysis of variance using a non-parametric test, Kruskal-Wallis test to ascertain the most important constraints 
among the five sets of constraints as perceived by different groups.

\section{FINDINGS AND DISCUSSION}

The test statistics value of KruskalWallis one-way ANOVA and its level of significance is given in Table 1. It is clear from the table that test statistic corresponding to personal constraints was most important among different sets of constraints which is in line with the studies of Resmy et al.,
(2001) who found that the lack of knowledge was the major problem of majority of small farmers (88.30\%) and big farmers (93\%) than other constraints in adoption of sustainable practices in coconut and banana in Alappuzha district of Kerala state. Personal constraints were followed by economic and promotional and infrastructural constraints. Social constraints and ecological constraints were not significantly different among groups.

Table 1.

Comparison of Different Constraints as per Kruskal-Wallis Test

\begin{tabular}{|l|c|c|}
\hline \multicolumn{1}{|c|}{ Constraints } & Test statistics & p value \\
\hline Economic & 35.86 & \\
\hline Promotional and infrastructural & 25.29 & \multirow{2}{*}{$<0.0001$} \\
\hline Social Social & 0.85 & \\
\hline Personal & 39.19 & \\
\hline Ecological & 0.00 & \\
\hline
\end{tabular}

Further analysis was done for each of the constraint categories and the following were the results.

\section{Economic Constraints}

Kruskal-Wallis test results showed that the economic constraints were significantly different among three livelihood categories. Hence, it can be inferred that the level of influence of economic constraints to different groups was different according to their perception (Table 2). To explore it further, multiple comparisons procedure was adopted to identify the group, which is more prone to economic constraints. It shows that mean rank of group 2 (non-farm alone) is least and this group is less vulnerable followed by group 3 (farm + non-farm) and group 1 (farm alone). Sarah et al., (2003) also reported that majority of the respondents (92.50\%) faced financial problems as the major constraints.

Table 2.

Comparison of Economic Constraints Based on Mean Ranks

$(n=120)$

\begin{tabular}{|c|c|c|c|}
\hline Particulars & Mean Ranks & Test statistics & p value \\
\hline Group 1 & $113.19 \mathrm{a}$ & & \\
\cline { 1 - 2 } Group 2 & $49.33 \mathrm{~b}$ & \multirow{2}{*}{$35.86^{* *}$} & $<0.0001$ \\
\hline Group 3 & $58.95 \mathrm{~b}$ & & \\
\hline
\end{tabular}

Mean ranks with same letters were not significantly different with each other ${ }^{* *}$ Significant at $1 \%$ level of significance 


\section{Promotional and Infrastructural Constraints}

For this set of constraints too Kruskal-Wallis test statistic value was significant at 1 per cent level of significance (Table 3). Hence, perceptions of three groups were different. Results of multiple comparison shows that group 2 and 3 were not significantly different in this. But group 1 is significantly different from other two groups. Deepak (2003) in his study revealed that cent per cent of the farm women beneficiaries suggested that training should be organized based on practiced field problems, training should be imparted by using simple local language words rather than using technical words, the subject matter should have photographs/illustrations, rather than being theoretical oriented, more training should be organized on agrobased subsidiary enterprises and more importance to be given on integrated pest management.

Table 3.

Comparison of Promotional and Infrastructural Constraints Based on Mean Ranks

$(\mathrm{N}=120)$

\begin{tabular}{|c|c|c|c|}
\hline Particulars & Mean Ranks & Test statistics & p value \\
\hline Group 1 & $105.69^{\mathrm{a}}$ & & \multirow{2}{*}{$25.29^{* *}$} \\
\cline { 1 - 2 } Group 2 & $54.13^{\mathrm{b}}$ & $<0.0001$ \\
\hline Group 3 & $55.91^{\mathrm{b}}$ & & \\
\hline
\end{tabular}

Mean ranks with same letters were not significantly different with each other

**Significantly different at $1 \%$ level of significance

\section{Social Constraints}

It is clear from the table that the difference between different groups on social constraints is not significantly different. Mean ranks of three groups indicated that social constraints for group 1 are more followed by group 3 and group 2 (Table 4).

Table 4.

Comparison of Social Constraints based on Mean Ranks

$(n=120)$

\begin{tabular}{|c|c|c|c|}
\hline Particulars & Mean Ranks & Test statistics & p value \\
\hline Group 1 & $66.58^{\mathrm{a}}$ & & \\
\hline Group 2 & $57.97^{\mathrm{a}}$ & 0.85 & 0.654 \\
\hline Group 3 & $61.58^{\mathrm{a}}$ & & \\
\hline
\end{tabular}

Mean ranks with same letters were not significantly different with each other 


\section{Personal Constraints}

Test statistic value for personal constraints (Table 5) shows that all the three groups are significantly different at one per cent level of significance. Group 2 and 3 are on par regarding personal constraints. Personal constraints of group 1 are more significantly different from other two groups.

Table 5.

Comparison of Personal Constraints based on Mean Ranks

$(n=120)$

\begin{tabular}{|c|c|c|c|}
\hline Particulars & Mean Ranks & Test statistics & p value \\
\hline Group 1 & $114.00^{\mathrm{a}}$ & & \\
\cline { 1 - 2 } Group 2 & $53.19^{\mathrm{b}}$ & \multirow{2}{*}{$39.19^{* *}$} & $<0.0001$ \\
\hline Group 3 & $54.83^{\mathrm{b}}$ & & \\
\hline
\end{tabular}

Mean ranks with same letters were not significantly different with each other

**Significantly different at $1 \%$ level of significance

\section{Ecological Constraints}

Table 6 shows that test statistic value for ecological constraints were 0.00. It means that three groups were not significantly different regarding ecological constraints. It can be attributed to its small geographical area and the constraints regarding ecological problems are common to all the three groups.

Table 6

Comparison of Ecological Constraints based on Mean Ranks

$(n=120)$

\begin{tabular}{|c|c|c|c|}
\hline Particulars & Mean Ranks & Test statistics & p value \\
\hline Group 1 & $60.50^{\mathrm{a}}$ & & \\
\cline { 1 - 2 } Group 2 & $60.50^{\mathrm{a}}$ & \multirow{2}{*}{0.00} & 1.00 \\
\hline Group 3 & $60.50^{\mathrm{a}}$ & \\
\hline
\end{tabular}

Mean ranks with same letters were not significantly different with each other

\section{CONCLUSION}

From the results of analysis for different constraints, it is obvious that all the enlisted constraints were important in one way or the other. To ensure the sustainability of any livelihood system personal and economic constraints play a significant role. However, those related to the promotional and infrastructural aspects had a major role in creating obstacles to livelihood security. Farm sector diversification through animal husbandry, poultry and fisheries and its measurement in terms of value of outputs is a viable strategy for study area. The extension of farming activities to certain on-farm post harvest operations not only adds to the farm - gate value creation but also expands the production entrepreneurship of the farmers to services. 


\section{REFERENCES}

Chambers, R. (1988). Sustainable rural livelihoods: A key strategy for people, environment and development. In the greening of AIDS, C. Conroy \& M. Lituinoff (eds), Earthscan, London.

Deepak, M. P. (2003). A study on perception of beneficiaries and non-beneficiaries towards WYTEP programme in Dharwad district. Unpublished M. Sc. (Agri.) Thesis, University of Agricultural Sciences, Dharwad, Karnataka, India.

Letha Devi, G. (2007). Changing livelihood pattern of rural women: An analysis in the context of urbanization. Unpublished Ph. D. Thesis, Division of Agricultural Extension, Indian Agricultural Research Institute, New Delhi, India.

Resmy, C., Shivamurthy, M. \& Varshatapre (2001). Constraints in adoption of suitable practices in coconut and banana. Indian Journal of Extension Education, 37(1 \& 2): 99-101.

Sarah, K. T. \& Atchuta, R. K. (2003). Problems faced by farm women in managing enterprises. MANAGE Extension Research Review, pp.74-78.

Savitha, S. S. (2004). Role of rural women in animal husbandry. Unpublished M. Sc. (Agri.) Thesis, University of Sciences, Dharwad, Karnataka, India.

Swaminathan, M.S. (1991a). Greening of the mind. Indian Journal of Social Work, 52 (3): 401-407.

Swaminathan, M.S. (1991b). From Stockholm to Rio de Janeiro: the road to sustainable agriculture. Monograph No. 4, MS Swaminathan Research Foundation, Madras. 